\title{
Microflora in the Hemolymph of Japanese Coastal Crustacea
}

Short Paper

\author{
Ryutaro Ueda,* Haruo Sugita,* \\ and Yoshiaki Deguchi*
}

(Received March 8, 1993)

It has been recognized that the hemolymph collected from healthy specimens of marine invertebrates is germ-free. ${ }^{1)}$ However, Tubiash et al. $^{2}$ isolated a large number of bacteria from the hemolymph collected from healthy specimens of blue crab Callinectes sapidus, with high frequencies of occurrence. Additionally, Davis and Sizemore found that these bacteria included food poisoning causative agents such as Vibrio cholerae, $V$. parahaemolyticus, and $V$. vulnificus. ${ }^{3}$ ) However, it remains to be clarified whether this phenomenon is applicable to other crustaceans. In the present study, therefore, we investigated the microflora in the hemolymph of coastal crustaceans, including four species of crabs and a hermit.

Five specimens of Plagusia dentipes and Schizophrys aspera, three of Atergatis reticulatus, and two of Atergatis floridus, along with five of a hermit crab Aniculus aniculus, were caught around Shimoda, Shizuoka Prefecture, Japan. All the specimens were ascertained to be healthy, based on appearance, with no symptom of disease and no injury. Each specimen was cooled on ice and transported to Shimoda Marine Laboratory, Nihon University within $1 \mathrm{hr}$. After the body surface of each specimen had been swabbed with $70 \%$ ethanol and burnt slightly with a flame, the hemolymph was collected from the pericardial sinus with a sterile syringe and immediately placed onto PYBG and 1/20PYBG agar plates. 4 ) The inoculated plates were incubated at $20^{\circ} \mathrm{C}$ for 5 days under aerobic conditions. After incubation, about 20 bacterial colonies were isolated at random from each plate and the microfiora was determined as reported previously. ${ }^{4)}$

As a result, heterotrophic bacteria were detected in all the specimens of five crustacean species examined with mean total viable counts ranging from $1.6 \times 10^{3}$ to $1.8 \times 10^{4} \mathrm{CFU} / \mathrm{ml}$. A total of 729 strains of bacteria were isolated, which include the following six genera: Vibrio (587 strains), Pseudomonas (95), Flavobacterium (27), Staphylococcus (7), Micrococcus (7), and coryneforms (6). Table 1 shows the distribution of these bacteria in the hemolymph of coastal crustaceans examined. Genera Vibrio and Pseudomonas occurred predominantly in $60-100 \%$ specimens of each animal species. Sizemore et al. ${ }^{\mathrm{s})}$ reported that Vibrio, Pseudomonas, Acinetobacter, Bacillus, Flavobacterium, and coryneforms were predominant in the hemolymph of blue crab. These results strongly suggest that the heterotrophic bacteria, especially Vibrio and Pseudomonas are distributed widely even in the hemolymph of healthy specimens of coastal Crustacea. Sizemore and David ${ }^{\text {y) }}$ examined the Vibrio strains isolated from the hemolymph, surface of carapace, gill, and gut of blue crab on the basis of 124 biochemical characters, and reported that bacteria found in hemolymph derived from the surface of carapace. However, it remains unresolved whether this conclusion is applicable to all the bacteria occurring in other crustacean hemolymph. Furthermore, it is known that Crustacea possesses some self-defense mechanisms such as agglutinins, bacteriocidins and precipitins in their hemolymph. ${ }^{7}{ }^{8}$ Therefore, relationships between these defense factors and bacteria in the hemolymph should be analyzed for a better understanding of the self-defense mechanism of coastal Crustacea. Further studies along this line are now in progress.

\section{References}

1) F. B. Bang: in "A Symposium on Diseases of Fishes and Shellfishes" (ed. by S. F. Snieszko), American Fisheries Society, Washington D. C., 1970, pp. 383-404.

2) H.S. Tubiash, R. K. Sizemore, and R. R. Colwell: Appl

3) J. W. Davis and R. K. Sizemore: Appl. Environ. Microbiol.,

4) H.Sugita, H. Tanaami, T. Kobashi, and Y. Deguchi: Nippon Suisan Gakkaishi, 47, 655-661 (1981)

5) R. K. Sizemore, R.'R. Colwell, H.S. Tubiash, and T. E Lovelace: Appl. Microbiol., 29,393-399 (1975).

6) R.K. Sizemore and J. W. Davis: J. Invertebr. Pathol., 46, R. Ueda $110(1985)$

R. Ueda, $\mathrm{H}$. Sugita ${ }_{3}$ and $\mathrm{Y}$. Deguchi: Nippon Suisan Gakkaishi, 57, 69-78 (1991).

. Paterson, J. W. Cornick, and J. E. Stewart: J. Invertebr, Pathol., 27, 95-104 (1976).

Table 1. Microflora of the hemolymph collected from Japanese coastal crustaceans

\begin{tabular}{|c|c|c|c|c|}
\hline Genus & $\begin{array}{l}\text { Plagusia dentipes } \\
(n=5)^{* 1}\end{array}$ & $\begin{array}{c}\text { Schizophrys aspera } \\
(n=5)\end{array}$ & $\begin{array}{l}\text { Atergatis spp. } \\
\quad(n=5)\end{array}$ & $\underset{(n=5)}{\text { Aniculus aniculus }}$ \\
\hline $\begin{array}{l}\text { Vibrio } \\
\text { Pseudomonas } \\
\text { Flavobacterium } \\
\text { Staphylococcus } \\
\text { Micrococcus } \\
\text { Coryneforms }\end{array}$ & $\begin{array}{c}3.72 \pm 0.50 \quad(100) * 2 \\
3.26 \pm 0.22 \quad(60) \\
2.98 \pm 0.12(60) \\
=(0) \\
2.70 \pm 0.08(40) \\
-(0)\end{array}$ & $\begin{array}{c}2.42 \pm 1.03(100) \\
2.54 \pm 0.87(100) \\
1.30(20) \\
-\quad(0) \\
-\quad(0) \\
-\quad(0)\end{array}$ & $\begin{array}{c}3.68 \pm 1.00(100) \\
2.56 \pm 1.13(100) \\
-* 3(0) \\
2.93(33) \\
-(0) \\
-(0)\end{array}$ & $\begin{array}{ll}4.06 \pm 0.74 & (100) \\
3.11 \pm 0.77 & (80) \\
3.13 \pm 0.32 & (80) \\
2.75 \pm 0.59 & (80) \\
2.41 \pm 0.11 & (40) \\
2.66 \pm 0.15 & (40) \\
\end{array}$ \\
\hline Total viable count & $3.81 \pm 0.53$ & $3.20 \pm 0.88$ & $3.88 \pm 1.01$ & $4.25 \pm 0.63$ \\
\hline
\end{tabular}

*1 Number of specimens.

*2 Mean \pm standard deviation of viable counts $(\log \mathrm{CFU} / \mathrm{m} l)($ occurrence, $\%$ )

- Not detected.

* Department of Fisheries, Nihon University, Shimouma, Setagaya, Tokyo 154, Japan（上田龍太郎, 杉田治男, 出口吉昭: 日本大学農缺医学部水産学科)。 